УДК 330.342:338.2

DOI: https://doi.org/10.32689/2618-0065-2020-2(4)-356-369

Терещенко Діна Акрамівна, кандидат наук з державного управління, доцент, докторант навчально-науково-виробничого центру, Національний університет цивільного захисту України, 61024, м. Харків, вул. Лермонтовська, 28, тел. (066) 827-76-61, e-mail: dtereshchenko7754367@ukr.net, https//orcid.org/0000-0003-0633-0097

\title{
НАПРЯМИ ВДОСКОНАЛЕННЯ КОМУНІКАТИВНОГО ЗАБЕЗПЕЧЕННЯ ДЕРЖАВНОГО РЕГУЛЮВАННЯ ФОРМУВАННЯ ЛЮДСЬКОГО КАПТТАЛУ В УКРАЇНІ
}

Анотація. У статті досліджено сутність та особливості комунікативного забезпечення державного регулювання формування людського капіталу в Україні. Зазначено, що становлення ефективної взаємодії владних органів різного рівня з громадськістю залежить від якісних змін моделі державного управління в Україні. Здійснено аналіз моделей державного управління (Old Public Management; New Public Management; Good Governance). Надано рекомендації щодо використання принципів нового публічного менеджменту і належного врядування для вдосконалення механізму взаємодії між суб'єктами і об'єктами державного регулювання формування людського капіталу в Україні.

Розроблено механізм управління комунікаціями між владою, бізнесом та суспільством в контексті реалізації державної політики щодо формування і розвитку людського капіталу, функціонування якого передбачає не тільки інформування населення, а й налагодження партнерської взаємодії, ефективного зворотного зв'язку, проведення відповідної роз'яснювальної роботи, встановлення громадського контролю за діяльністю органів державного управління та органів місцевого самоврядування.

В рамках запропонованого механізму здійснено перенесення акцентів уваги державного управління від оперативних задач використання окремих елементів маркетингу до стратегічних завдань формування стабільних груп лояльних стейкхолдерів за рахунок впровадження системи та інструментарію маркетингу партнерських відносин. Розкрито роль основних засобів інтегрованих маркетингових комунікацій (паблік рілейшнз, прямий маркетинг, державна реклама) в досягненні стратегічних цілей державного регулювання формування людського капіталу.

Наголошено, що вирішення комплексної проблеми формування людського капіталу потребує взаємодії всіх зацікавлених сторін у певній сфері 
(охорони здоров`я, освіти та науки, культури, екологічної безпеки, надання публічних послуг тощо), відтак головним науковим завданням стає розробка організаційно-правових заходів щодо імплементації принципів врядування в практику владних структур у трьох основних напрямах: розвиток державноприватного партнерства, розвиток системи надання публічних послуг та створення сприятливих умов для ефективної взаємодії різних рівнів публічної влади (центрального, регіонального, місцевого).

Ключові слова: державне регулювання, державна реклама, зв’язки 3 громадськістю, комунікації, механізми, прямий маркетинг, людський капітал

Tereshchenko Dina Akramovna, PhD in Public Administration, Associate Professor, doctoral student of educational-scientific-production center, National University of Civil Protection of Ukraine, 61024, Kharkiv, Str. Lermontovs'ka, 28, tel.: (066) 827-76-61, e-mail: dtereshchenko7754367@ukr.net, https//orcid.org/0000-0003-0633-0097

\section{DIRECTIONS OF IMPROVEMENT OF COMMUNICATIVE PROVISION OF STATE REGULATION OF HUMAN CAPITAL FORMATION IN UKRAINE}

Abstract. It was investigated in the article the peculiarities and essence of communicative provision of state regulation of human capital formation in Ukraine. It is noted that the establishment of effective interaction of different levels of government bodies with the public depends on qualitative changes in the model of public administration in Ukraine. The models of public administration (Old Public Management; New Public Management; Good Governance) are analyzed. Recommendations were given on the application of the principles of new public management and good governance to improve the mechanism of interaction between the subjects and objects of state regulation of human capital formation in Ukraine.

Designed by mechanism of management of communications between the government, business and society in the context of the implementation of state policy on the formation and development of human capital, the functioning of which provides not only informing the population, but also establishing partnerships or effective feedback, conducting appropriate publicity work, establishing public control on the activity of state and local self-government bodies.

It was carried out within the framework of the proposed mechanism for transfer the accents of attention of public administration attention from the operational tasks of using separate elements of marketing to the strategic tasks of forming stable groups of loyal stakeholders through the implementation of a system and tools for marketing partnerships. Disclosed of the role of fixed assets of integrated marketing communications (public relations, direct marketing, public advertising) in achieving the strategic goals of the state regulation of human capital formation. 
It was emphasized, that addressing the complex problem of human capital formation requires the involvement of all stakeholders in a particular field (health, education and science, culture, environmental security, public services, etc.), therefore, the main scientific task is to develop organizational and legal measures to implement the principles of governance in the practice of government structures in three main areas: the development of public-private partnerships, the development of public service delivery system and the creation of favorable conditions for effective interaction of different levels of public power (central, regional, local).

Keywords: state regulation, state advertising, public relations, communications, mechanisms, direct marketing, human capital

Постановка проблеми. Забезпечення стійких темпів соціальноекономічного розвитку, залучення інвестицій як в основні засоби та технології, так і в людський капітал відповідно до запропонованої Урядом України стратегії економічного зростання [1], неможливе без ефективної взаємодії органів державної влади, бізнесу та суспільства (людини). Відповідно до названої Стратегії «до 2024 року Україна має перейти до топової групи індексу людського капіталу, а середня тривалість життя вирости до 75 років».

Поряд 3 цим, «на сьогоднішній день, на рівні офіційних інституцій система державного управління людським розвитком представлена окремими елементами, наприклад, управління освітою, охороною здоров'я, зайнятістю, соціальним захистом. Ці елементи $є$ багаторівневими системами, що побудовані за ієрархічним принципом, згідно з яким визначаються: обсяг управління на кожному рівні, послідовність та підпорядкованість рівнів управління, розподіляються функції по вертикалі та горизонталі, обов'язки, права та відповідальність. На кожному рівні управління, розміщення елементів і форма їх зв'язків передбачає певну автономію. Це призводить до відсутності: по-перше, комплексного підходу до проблеми управління людським розвитком; по-друге, відповідальності за наявний результат» [2, с.230].

Існує необхідність як структурних перетворень, так і нових підходів до розмежування функцій між органами державної влади та місцевого самоврядування. Забезпечення їх оптимальної взаємодії - один з пріоритетних напрямів організації публічної влади на місцях, оскільки від нього залежить вирішення проблем локального, місцевого характеру. Для ефективного здійснення цієї функції необхідна взаємна підтримка цих органів, погодженість і єдина спрямованість їхніх дій [3].

Усе це, безперечно, вимагає перегляду традиційних підходів до методів і механізмів прийняття рішень, стереотипів управлінського мислення державних/публічних службовців та перехід до сучасних моделей державного управління, нових механізмів налагодження партнерства і міжсекторної співпраці, взаємодії органів державної влади, місцевого самоврядування, бізнесу і суспільства в контексті реалізації заходів щодо регулювання 
формування і розвитку людського капіталу в Україні.

Аналіз останніх досліджень і публікацій. Сучасні підходи до трансформації публічного управління висвітлено у працях таких учених, як С. Домбровська, Д. Кетл, Ю. Ковбасюк, Д. Красільніков, Н. Леоненко, С. Майстро, В. Мороз, Т. Поспєлова та ін. Концептуальні засади теорії комунікації владних структур, розвитку зв'язків із громадськістю, маркетингових комунікацій органів публічного управління знайшли своє відображення в роботах В. Козакова, М. Лашкіної, М. Логунової, Г. Почепцова, О. Рашковської, В. Ребкала, Є. Романенка та ін.

Незважаючи на значну кількість наукових доробків щодо реформування системи державного управління, зокрема іiі інформаційно-комунікативної підсистеми, питання функціонування механізмів взаємодії системи органів влади, бізнесу та суспільства, їх оптимізації з метою формування і розвитку людського капіталу в Україні, $є$ недостатньо вивченими, що зумовлює необхідність подальших дослідницьких зусиль у цьому напрямі.

Мета статті полягає в обгрунтуванні теоретичнх основ та розробленні практичних рекомендацій щодо вдосконалення комунікативного забезпечення державного регулювання формування людського капіталу в Україні на засадах сучасних концепцій державного управління (New Public Management; Good Governance).

Виклад основного матеріалу. Неоціненну роль у державному управлінні відіграють інформаційно-комунікативні процеси. По суті саме управління - це не що інше, як здійснення цілеспрямованих комунікативних контактів людей, які обмінюються й споживають певну інформацію. У цьому контексті можна говорити, що наявні і майбутні способи створення суспільних благ і якість методів управління соціумом радикально залежать і залежатимуть від інформаційно-комунікативних зв'язків [4, с. 30].

У сучасному цивілізованому світі комунікаціям між структурами, що здійснюють державну владу й управління суспільством відводиться центральне місце в кожній політичній системі. 3 позиції демократії, саме комунікація $€$ ключовим елементом при формуванні суспільства, в якому громадяни і держава відчувають свій взаємозв'язок. Звідси визначається іiі стимулююча роль. Головна мета комунікації - створення довірливих відносин між зацікавленими сторонами, формування правильних очікувань $з$ боку громадськості та налагодження партнерських стосунків між суб'єктами комунікації [5, с. 10]. Водночас «комунікації у публічному просторі» розглядаються нами як ефективний управлінській засіб розвитку та реалізації заходів, необхідних для досягнення поставлених цілей [6].

Сьогодні теоретиками та практиками розглядаються три основних підходи до вдосконалення існуючої організаційної структури системи 
державного управління, а отже і системи комунікацій: ієрархічна, «ринок», «мережа» (табл. 1). В рамках першої моделі в системі державного управління існує сувора ієрархія владних структур, в тому числі й представницьких органів; державне управління розглядається як «раціональна бюрократія», побудована на відносинах, які розглядаються у вертикальній проекції. Названа модель передбачає жорстке централізоване управління, дотримання норм, стандартів, планів, що на практиці породжує такі організаційні недоліки, як: неповороткість, розростання держапарату, ігнорування необхідності підвищення цінності державних послуг та врахування інтересів населення в процесі прийняття державно-управлінських рішень.

Таблиця 1. Організаційна структура та моделі державного управління

\begin{tabular}{|c|c|c|c|c|c|}
\hline $\begin{array}{l}\text { Орг. } \\
\text { структура/ } \\
\text { Методологія }\end{array}$ & $\begin{array}{l}\text { Тип } \\
\text { організа- } \\
\text { ційної } \\
\text { структури } \\
\text { управління }\end{array}$ & $\begin{array}{l}\text { Тип } \\
\text { управління }\end{array}$ & $\begin{array}{l}\text { Модель } \\
\text { державного } \\
\text { управління }\end{array}$ & Фокус моделі & Вид комунікацій \\
\hline $\begin{array}{l}\text { «Жорстка»/ } \\
\text { Контроль та } \\
\text { підзвітність }\end{array}$ & $\begin{array}{l}\text { Iєрархічна } \\
\text { (складна } \\
\text { орг. } \\
\text { структура) }\end{array}$ & $\begin{array}{l}\text { Контроль і } \\
\text { управління }\end{array}$ & $\begin{array}{l}\text { Old Public } \\
\text { Management } \\
\text { (Класичне } \\
\text { державне } \\
\text { управління) }\end{array}$ & $\begin{array}{l}\text { Процедури } \\
\text { (раціональна } \\
\text { бюрократія) }\end{array}$ & $\begin{array}{l}\text { Сильні } \\
\text { вертикальні } \\
\text { комунікації }\end{array}$ \\
\hline $\begin{array}{l}\text { «М'яка»/ } \\
\text { Плюралис- } \\
\text { тична } \\
\text { незалежність }\end{array}$ & $\begin{array}{l}\text { «Ринок» } \\
\text { (проста } \\
\text { орг. } \\
\text { структура) }\end{array}$ & $\begin{array}{l}\text { Управління } \\
\text { (організацій- } \\
\text { но- } \\
\text { діяльнісне) }\end{array}$ & $\begin{array}{l}\text { New Public } \\
\text { Management } \\
\text { (Новий } \\
\text { публічний } \\
\text { менеджмент) }\end{array}$ & $\begin{array}{l}\text { Еффект, } \\
\text { результат } \\
\text { (менеджери- } \\
\text { зація та } \\
\text { маркетизація) }\end{array}$ & $\begin{array}{l}\text { Слабкі } \\
\text { вертикальні, } \\
\text { посилення } \\
\text { горизонтальних } \\
\text { комунікацій }\end{array}$ \\
\hline $\begin{array}{l}\text { Проектна/ } \\
\text { Взаємо- } \\
\text { залежність }\end{array}$ & «Мережа» & $\begin{array}{l}\text { Управління } \\
\text { (політичне, } \\
\text { інституціо- } \\
\text { нальне, реф- } \\
\text { лексівно-ко- } \\
\text { мунікативне) }\end{array}$ & $\begin{array}{l}\text { Good } \\
\text { Governance } \\
\text { (Належне } \\
\text { Врядування) }\end{array}$ & $\begin{array}{l}\text { Участь i } \\
\text { партнерство }\end{array}$ & $\begin{array}{l}\text { Сильні } \\
\text { горизонтальні, } \\
\text { «мережеві» } \\
\text { комунікації }\end{array}$ \\
\hline
\end{tabular}

[розробка автора на основі [7]

Друга модель - NPM - орієнтована на підвищення гнучкості прийняття рішень у державному апараті, зменшення його ієрархічності, посилення механізмів зворотного зв `язку між державою та громадянами. Серед рис моделі NPM можна виокремити простоту організаційної структури управління 3 невеликою кількістю ієрархічних рівнів, на відміну від традиційної бюрократичної структури 3 безліччю ієрархічних рівнів; поєднання «жорсткості» і «м'якості» (реалізація основних цілей контролюється згори, водночас нижні ієрархічні рівні самостійні в діях, що сприяє досягненню цілей); ринкові механізми координації комунікації.

Поширення ідей NPM сприяло «перепрограмуванню» західної системи 
державного управління, руйнуванню «закостенілих» бюрократичних структур, перетворенню їх у більш чутливі до економічної кон'юнктури й запитам суспільства, прозорі для громадського контролю, підзвітні політичному керівництву і в цьому сенсі більш ефективні [8].

Модель сучасного державного управління NPM грунтується на двох ключових елементах - менеджеризації та маркетизації; передбачає підвищення гнучкості управління, готовності до змін. Д. Кетл визначає шість основних характеристик моделі державного управління NPM [9]: продуктивність, маркетизація, орієнтація на клієнтів, децентралізація, орієнтація на цілі, звітність за результатами. Серед країн, які визнали ефективність моделі NPM США, Великобританія, Швеція, Німеччина, Франція, Нідерланди, Нова Зеландія та ін. Серед успішних практик впровадження інструментів NPM можна виокремити: запровадження пілотних проектів, маркетингових інструментів, практики бенчмаркінгу.

В рамках мультимодального державного управління (Good Governance) переважають «мережеві» комунікації. За допомогою численних інститутів обміну ресурсами, інформацією, узгодження політики і рішень мережева модель державного управління пропонує нові форми комунікації громадян 3 політичним керівництвом держави і державними службовцями, а отже - нові форми контролю, підзвітності та механізми узгодження інтересів. Мережеві моделі передбачать перехід від системи розподілу державних ресурсів, до системи обміну ресурсами між учасниками мережі. Ціннісним аспектом у даному випадку є сильні горизонтальні взаємозв'язки і самоорганізація мережі. Вертикальні (субординаційні) зв'язки є достатньо слабкими при зовнішній взаємодії органів влади з іншими публічними інститутами.

До прикладів типових конструкцій управлінських мереж в Україні можна віднести державно-приватне партнерство (участь бізнесу та громадянського суспільства у наданні публічних послуг); грантові та контрактні угоди, коли держава передає функції з надання послуг некомерційним організаціям та бізнесу; коаліції зацікавлених груп; відносини кооперації та співробітництва 3 регіонами СС.

Незважаючи на те, що концепції NPM i Governance активно впроваджуються в систему державного управління багатьох країн, світовий досвід реформування державного управління продемонстрував неспроможність ідеї повної відмови від бюрократичної моделі державного управління. Саме бюрократія є гарантом дотримання громадського інтересу i обмежує домінування вузько групових інтересів бізнесу в процесі налагодження взаємодії з державою, не заперечуючи ієрархії. На думку автора, процес побудови механізмів державного регулювання формування і розвитку людського капіталу в Україні має передбачати системне поєднання кращих характеристик концепцій бюрократичної моделі (класичного державного управління), нового державного менеджменту та «належного врядування» 
(зокрема, мережевого державного управління) [10, с.132-135].

Таким чином, здійснений аналіз свідчить, що оптимальною моделлю управління комунікаціями системи органів влади, спрямованої на регулювання процесів формування людського капіталу може бути сімбіоз трьох названих концепцій. Для запровадження цих змін, спираючись на зарубіжний досвід («на Заході в органах державного управління немає відділів зі зв'язків із громадськістю: вони називаються відділами комунікацій [11, с. 20-21]»), можна створити Державне агентство 3 питань комунікації - центральний орган виконавчої влади (ЦОВВ), поклавши на нього функції з реалізації державної комунікативної політики щодо формування людського капіталу, розвитку інформаційно-комунікативного суспільства. Перевагами такого підходу є: формування та проведення єдиної державної політики у різних сферах формування людського капіталу (освіти, охорони здоров'я, соціального захисту, екологічної безпеки та ін.); підвищення рівня керованості та координації; усунення розпорошеності сфери; підвищення статусу координаційного органу та можливостей впливу на сферу; усунення дублювання функцій та завдань ЦОВВ. Також можна в існуючій розподіленій структурі ЦОВВ, органів місцевого самоврядування, що відповідають за розвиток комунікації, інформаційне суспільство та електронне урядування, уточнити лише їх цілі, завдання, функції, горизонтальні комунікації та їх зміст без створення додаткових державних органів. Перевагами другого підходу є: не потребує додаткових витрат (фінансових і часових) на свою реалізацію; відповідає загальному процесу децентралізації, деконцентрації та демократизації влади.

Практичне впровадження принципів сучасних концепцій нового публічного менеджменту і належного врядування передбачає зміни не лише в організації діяльності органів публічної влади, а й обумовлює активне використання кращих практик маркетингу. «На сучасному етапі маркетинг $\epsilon$ загальноприйнятою та визнаною управлінською концепцією, що має на меті збалансування економічних інтересів товаровиробника та споживача. Практики публічно-управлінської діяльності свідчать про те, що маркетинг поступово стає концепцією і успішно використовується органами державної влади та місцевого самоврядування [4, с. 231]».

На особливу увагу заслуговує маркетинг партнерських відносин, який дозволить вибудувати ланцюжок відносин не тільки всередині системи органів державного управління для забезпечення якості державних/публічних послуг, але й поза іï межами - 3 партнерами на ринку, з контактними аудиторіями, зі споживачами послуг тощо. У рамках маркетингового підходу до державного регулювання формування і розвитку людського капіталу в Україні, доцільно розробити механізм управління комунікаціями між владою, бізнесом та суспільством (далі - механізм комунікації) в контексті реалізації державної політики щодо формування і розвитку людського капіталу, який 
концептуально поєднає вплив комунікативних інструментів стратегічного маркетингу, маркетингу партнерських відносин і внутрішнього маркетингу (рис. 1).

Даний механізм забезпечує створення багаторівневого й мультисуб'єктного координаційного механізму, результат функціонування якого, залежить від здатності суб`єктів суспільних комунікації визначити спільну точку зору, мобілізувати компетенції різної природи й реалізувати дієві способи розподілу відповідальності й легітимізації прийнятих управлінських рішень, спрямованих на формування і розвиток людського капіталу. На рис. 1 відображено численні зв язки, які існують в системі формування і розвитку людського капіталу.

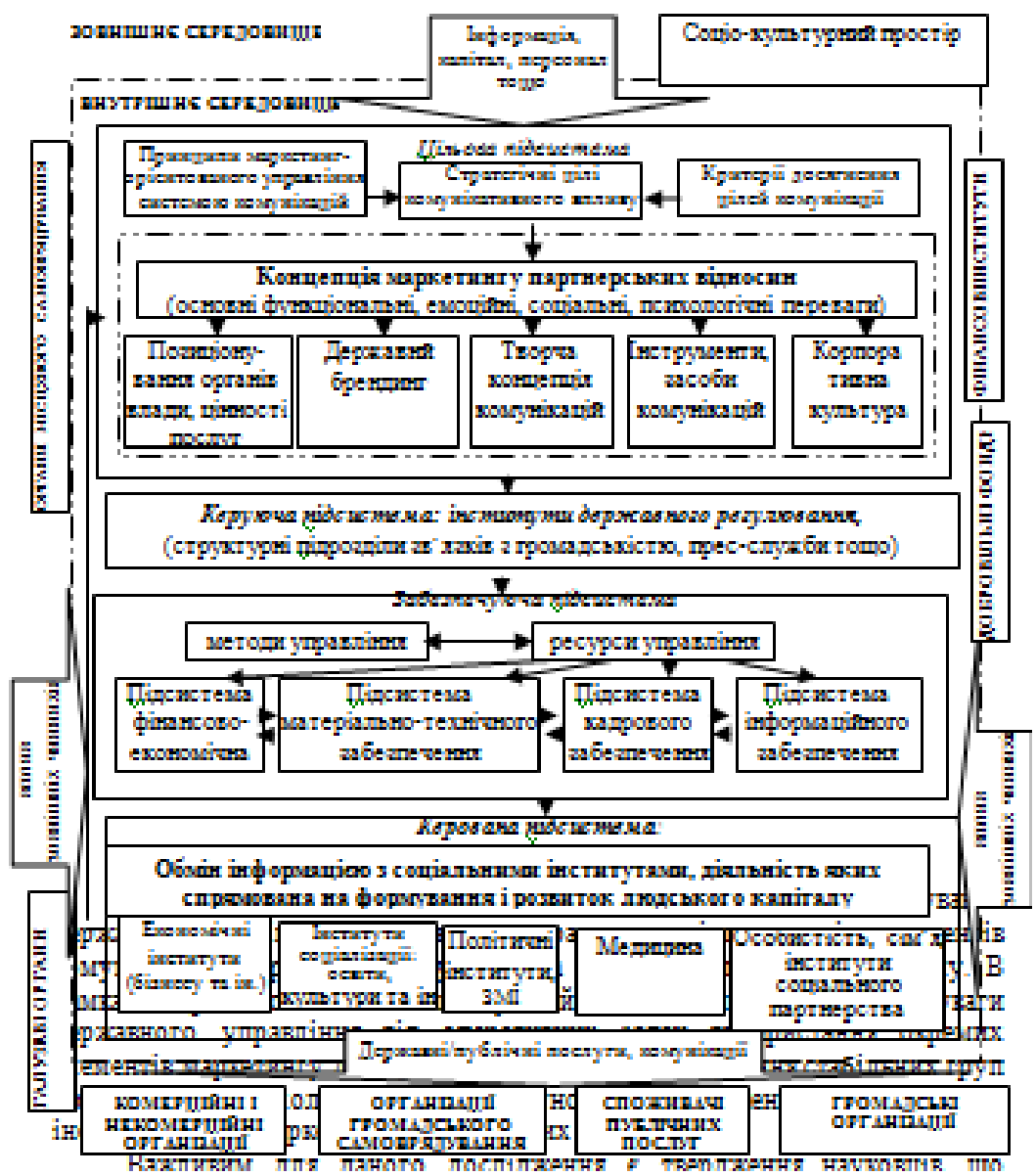

Рис. 1. Механізм управління комунікаціями між владою, бізнесом та суспільством в контексті реалізації державної політики щодо формування і розвитку людського капіталу

Консенсус досягається завдяки процедурі загального формування державно-управлінських рішень, що враховують інтереси різних агентів комунікацій в процесі формування та розвитку людського капіталу. В рамках запропонованого механізму здійснено перенесення акцентів уваги державного управління від оперативних задач використання окремих елементів маркетингу до стратегічних завдань формування стабільних груп 
лояльних стейкхолдерів за рахунок впровадження системи та інструментарію маркетингу партнерських відносин.

Важливим для даного дослідження $\epsilon$ твердження науковців, що «механізми управління мають формальну та неформальну площину своєї дії та розвитку. Формальний аспект функціонування механізмів управління обумовлюється інституціональним середовищем, у межах якого відбувається процес управління (сукупність офіціально визнаних норм, правил тощо). Неформальний аспект обумовлено релігійно-культурологічними особливостями суб'єктів та об'єктів управління. Таким чином, зміст механізмів управління може бути розкрито через організовану та цілеспрямовану діяльність суб'єктів управління у ії єдності з впливами (діями, протидіями тощо) домінуючих традицій та особливостей розвитку об'єкту управління» [12, с.141].

Спираючись на вищевикладене, можна стверджувати, що стратегічний підхід до формування комунікативного простору державного регулювання формування людського капіталу передбачає вихід за рамки традиційного набору таких категорій, як «цільові аудиторії», «інформаційні потоки», «інформаційний продукт» і перехід до комунікативного впливу на структури суспільства, на процеси проблем якості людського капіталу, національної безпеки і забезпечення національних інтересів, з урахуванням особливостей суб'єктів та об'єктів управління (зокрема, соціально-політикокультурологічних). Специфікою партнерства $€$ збереження кожним iз партнерів відносної самостійності в основних аспектах діяльності. Тож партнерство як вид спільної діяльності полягає в рівноправності ії учасників, що передбачає рівні права й обов`язки кожної зі сторін, а відтак, і взаємну відповідальність.

Мета функціонування запропонованого механізму управління комунікаціями - створення умов для досягнення взаєморозуміння й конструктивної взаємодії органів державної влади, місцевого самоврядування, політичних партій, суспільних об'єднань і організацій та ринкових інститутів у процесі реалізації соціально-значущих проектів, які спрямовуються на формування і розвиток людського капіталу. Досягнення цієї мети здійснюється шляхом регулювання процесів обміну інформацією, покращення комунікативних каналів та співробітництва, використання комунікативних технологій, скоординованих програм, планів, завдань, синхронізованих з дією комунікативних процесів і інструментів на національному рівні.

Серед основних функцій досліджуваного механізму слід виокремити: аналіз і регулювання суспільних відносин; розробка стратегії комунікативної діяльності органів державного управління та місцевого самоврядування; організація ефективного «зворотного зв'язку» органів влади 3 бізнесструктурами та суспільством (людиною); залучення громадськості до участі у процесі обговорення та прийняття рішень; моніторинг та оперативне 
реагування на індивідуальні потреби, запити цільових аудиторій внутрішнього і зовнішнього середовища; забезпечення ефективності комунікацій органів влади та максимального задоволення інтересів усіх учасників і суспільства; координація, контроль суспільної думки, стеження за процесами, що в ній відбуваються, спостереження за динамікою суспільних настроїв; встановлення громадського контролю за діяльністю органів державного управління та органів місцевого самоврядування.

Ключовими елементами, які формують суспільні відносини в системі формування і розвитку людського капіталу через маркетинг партнерських відносин, на думку автора, $є$ :

- система корпоративних стандартів (розроблення стандартів комунікації між органами державної влади, органами місцевого самоврядування, бізнесом і суспільством; формування стійкої системи культурних цінностей, культурного середовища, яке дозволить легитимізувати різноманітні ідеологічні конструкції; орієнтація на корпоративну культуру);

- державний брендинг (стратегія формування образу і репутації органів влади);.

- позиціонування (позиціонування органів влади як рівноправної сторони у взаємодіях з бізнесом, як постачальника послуг, відображення i моделювання не відкритості, а саме підпорядкованості влади; сегментація цільових аудиторій і інформаціних каналів, фокусування комунікацій, прив'язування комплексу асоціацій до легко впізнаних візуальних елементів);

- творча концепція, яка забезпечує чітке розуміння і сприйняття образу системи державного управління (визначає форму подання всієї інформації щодо системи державного управління та ії послуги, формує емоційний зв'язок; у сукупності з системою ідентифікації є інструментом накопичування або прив'язки асоціацій та зрозумілою, що швидко сприймається формою відображення сутності повідомлення);

- інструменти комунікацій (безпосередньо є носіями інформації, з яких цільові аудиторії отримують повідомлення від органів державного управління; сама якість інструментів теж є джерелом асоціацій, яка проектується на якість державних послуг).

Серед інструментів комунікацій особливу увагу слід звернути на інструменти інтегрованих маркетингових комунікацій органів державної влади, які б забезпечували підвищення обсягів кредиту довіри до них, працювали на престижність їх інститутів, супроводжували пропагандистську та роз'яснювальну діяльність, формували позитивний імідж сфери публічного управління. У сучасних умовах розвитку системи державного управління в Україні виникає об'єктивна необхідність розширення використання в діяльності органів влади PR-технологій. «Щоб відбулися позитивні зміни у 
зв'язках органів влади з громадськістю, потрібен перехід до розуміння комунікації як інструмента стратегічного управління (стратегічного менеджменту) [13, с. 37-38]».

У контексті реалізації державної комунікативної політики, спрямованої на формування і розвиток людського капіталу, стратегічну роль відіграє рекламна комунікологія (іміджева реклама, пропагандистська, диверсифікативна (провокативна) та інші). «Рекламна комунікологія у сфері публічного управління формує певні суспільні стереотипи, стандарти та цінності реалізації державної політики, забезпечуючи відповідні соціокультурні перетворення у суспільстві. Рекламна комунікологія на рівні діяльності органів державної влади являє собою специфічну сферу масових комунікацій між органами державної влади та різними аудиторіями 3 метою активного інформаційного, експресивного та прагматичного впливу на них, який має забезпечити вирішення основних, найактуальніших проблем розвитку суспільства, тим самим гарантуючи транспарентність системи публічного управління [4, с.119, 120]».

Рекламна комунікація, «що займає нішу інформатора, регулятора соціальної взаємодії» [14, с. 259], має бути спрямована на комунікативну ефективність державного регулювання формування людського капіталу.

Слушно зазначають українські дослідники О. С. Романенко та I. В. Чаплай, що на поточний момент спостерігається зростання ролі директмаркетингу як інструменту встановлення довгострокових відносин органів державного управління 3 громадянами (прямий маркетинг партнерських відносин). Зокрема, певні вигоди надає прямий маркетинг органам державної влади. Прямий маркетинг надає можливість вибору найбільш відповідного часу для взаємодії з їх аудиторіями. Крім того, при застосуванні директмаркетингу 3'являється можливість оперативної оцінки реакцій громадян на різні послуги державного управління та виявлення найбільш дієвих механізмів роботи $[15$, с. 76$]$. На погляд автора, указані дослідники досить вірно визначили сильні позиції даного засобу комунікацій та його особливості в державному управлінні.

Таким чином, вирішення проблеми вдосконалення комунікативного забезпечення державного регулювання формування людського капіталу в Україні потребує нетрадиційних підходів, що грунтуються на сучасній методологічній базі, яка враховує потенціал самоорганізації соціальнотериторіальних систем, вплив глобалізації, інформатизації, регіоналізації суспільного життя на децентралізацію публічної влади, посилення ролі інформації, знання, гуманітарних цінностей, неформальних компонентів взаємодії суб’єктів влади та суспільства як нематеріальних ресурсів розвитку.

Висновки. Отже, можна резюмувати, що вирішення комплексної проблеми формування людського капіталу потребує взаємодії всіх зацікавлених сторін у певній сфері (охорони здоров'я, освіти та науки, 
культури, екологічної безпеки, надання публічних послуг тощо), відтак головним науковим завданням стає розробка організаційно-правових заходів щодо імплементації принципів врядування в практику владних структур у трьох основних напрямах: розвиток державно-приватного партнерства, розвиток системи надання публічних послуг та створення сприятливих умов для ефективної взаємодії різних рівнів публічної влади (центрального, регіонального, місцевого).

Подальші дослідження необхідно спрямувати на пошук механізмів легітимності i керованості визначених процесів, їх регламентування на національному та регіональному рівнях. Вирішення окреслених проблем дозволить визначити i реалізувати основні напрями оптимізації процесу формування системи партнерської взаємодії, що сприятиме рівномірному розподілу економічних ресурсів, а отже, розвитку людського капіталу, виробництв i, як наслідок - соціально-економічному розвитку регіонів і країни.

\section{Jimepamypa:}

1. Стратегія економічного зростання: ВВП $+40 \%$ та 50 млрд дол США ПІІ до 2024 року. URL : https://www.kmu.gov.ua/news/vvp-40-ta-50-mlrd-dol-ssha-investicij-do-2024-rokuprezentovana-strategiya-ekonomichnogo-zrostannya

2. Поспєлова Т.В. Механізми державного управління людським розвитком в Україні: монографія. Донецьк: Норд-Прес, 2011. 350 с.

3. Майстро С.В. Розмежування повноважень органів державної влади та органів місцевого самоврядування. Державне будівництво. 2012. №1. URL: http://nbuv.gov.ua/UJRN/DeBu_2012_1_33.

4. Козаков В. М. Державно-громадянська комунікація: шлях від кризи до взаємодії: монографія / [В. М. Козаков, О. В. Рашковська, В. А. Ребкало, С. О. Романенко, І. В. Чаплай]. Київ: ДП “Вид. дім “Персонал”, 2017. 288 с.

5. Лашкіна М. Нові підходи до комунікації в публічному просторі державного управління. Публічне управління: теорія та практика. Вип. 1. 2013. С. 10-18.

6. Логунова М.М., М.Лашкіна, П.Гвоздик, А.Алєксєєв. Комунікації судової влади. К : АДЕФ. Украина, 2011.276 с.

7. Maracha V. Feedback Mechanisms in Public Administration System: VSM Application and Institutional Factors. Conference: 4th Business Systems Laboratory International Symposium «Governing Business Systems. Theories and Challenges for Systems Thinking in Practice». At: Mykolas Romeris University, Vilnius, Lithuania. URL: https://www.researchgate.net /publication/ 309239923_Feedback_Mechanisms_in_Public_Administration_System_VSM_Application_and_ Institutional_Factors.

8. Красильников Д.Г., Сивинцева О.В., Троицкая Е.А. Современные западные управленческие модели: синтез New Public Management и И Good Governance. ARS ADMINISTRANDI. 2014.2 № $2 . \quad$ C. $45-62 . \quad$ URL: file://D:/Users/Moyo1/Documents/Downloads/sovremennye-zapadnye.

9. Kettl D. The Global Public Management Revolution / D. Kettl. [S. p.: s. n.]. P. 3033.

10. Терещенко Д.А. Концептуальні підходи до формування механізмів державного регулювання розвитку людського капіталу. Україна у світових глобалізаційних процесах: культура, економіка, суспільство: тези доповідей. Міжнар. наук.-практ. конф., Київ, 25-26 берез., 2020 р. / М-во освіти і науки України; Київ. ун-т культури, Київ. нац. ун- 
т культури і мистецтв. Київ: Вид. центр КНУКіМ, 2020. 198 с. С.132-135.

11. Почепцов Г. Нові вимоги до комунікацій влади з населенням. Запровадження комунікацій у суспільстві. / Збірка статей за результатами круглого столу «Запровадження світових стандартів комунікації між владою та громадськістю - план дій для України» URL: http://www.fes.kiev.ua/new/wb/media/publikationen/Com_politics_FINAL.pdf

12. Домбровська С.М., Мороз В.М., Грень Л.М., Леоненко Н.А., Мороз С.А. Державне управління забезпеченням гендерної рівності в Україні: монографія. Х.:НУЦЗУ, 2018. $251 \mathrm{c}$.

13. Місцеве самоврядування в Україні: сучасний стан та основні напрями модернізації : наук. доп. / [ ред. кол. : Ю. В. Ковбасюк, К. О. Ващенко, В. В. Толкованов та ін.] ; за заг. ред. д-ра наук з держ. упр., проф. Ю. В. Ковбасюка. К. : НАДУ, 2014.128 с.

14. Park H., Blenkinsopp J. The roles of transparency and trust in the relationship between corruption and citizen satisfaction // International Review of Administrative Sciences. 2011. № 77 (2). P. 254-274.

15. Романенко С. О., Чаплай I. В. Система маркетингових комунікацій в механізмах державного управління. Актуальні проблеми економіки. 2016. № 4. С. 69-78.

\section{References:}

1. VVP $+40 \%$ ta 50 mlrd dol SShA PII do 2024 roku : Stratehiia ekonomichnoho zrostannia [+ 40\% of GDP and \$ 50 billion in FDI by 2024: economic growth strategy presented]. (2020). www.me.gov.ua. Retrieved from http://www.me.gov.ua/News/Detail?lang=uk-UA\&id=099695082d02-483d-a63a-5c9aa7675e38\&title=Vvp-40-Ta50-MlrdDolSshaPiiDo2024-RokuPrezentovanaStrategiiaEkonomichnogoZrostannia [in Ukrainian].

2. Pospielova, T.V. (2011). Mekhanizmy derzhavnoho upravlinnia liudskym rozvytkom $v$ Ukraini [Mechanisms of public administration of human development in Ukraine]. Donetsk: NordPres [in Ukrainian].

3. Maistro, S.V. (2012). Rozmezhuvannia povnovazhen orhaniv derzhavnoi vlady ta orhaniv mistsevoho samovriaduvannia [Separation of powers of state authorities and local self-government bodies]. Derzhavne budivnytstvo - State building, 1. Retrieved from http://nbuv.gov.ua/UJRN/DeBu_2012_1_33 [in Ukrainian].

4. Kozakov, V.M., Rashkovska, O.V., Rebkalo, V.A., Romanenko, Ye.O., \& Chaplai, I.V. (2017). Derzhavno-hromadianska komunikatsiia: shliakh vid kryzy do vzaiemodii [State-Civil Communication: The Way from Crisis to Interaction]. Kyiv: DP «Vyd. dim «Personal» [in Ukrainian].

5. Lashkina, M. (2013). Novi pidkhody do komunikatsii v publichnomu prostori derzhavnoho upravlinnia [New approaches to communication in the public space of public administration]. Publichne upravlinnia: teoriia ta praktyka - Public administration: theory and practice, 1, 10-18 [in Ukrainian].

6. Lahunova, M.M., Lashkina, M., Hvozdyk, P., \& Aleksieiev, A. (2011). Komunikatsii sudovoi vlady [Communications of the Judiciary]. Kyiv: ADEF. Ukraina [in Ukrainian].

7. Maracha, V. (2016). Feedback Mechanisms in Public Administration System: VSM Application and Institutional Factors. Conference: 4th Business Systems Laboratory International Symposium «Governing Business Systems. Theories and Challenges for Systems Thinking in Practice». At: Mykolas Romeris University, Vilnius, Lithuania. Retrieved from https://www.researchgate.net/publication/309239923_Feedback_Mechanisms_in_Public_Admini stration_System_VSM_Application_and_Institutional_Factors [in English]. 
8. Krasylnykov, D.H., Svyntseva, O.V., \& Troytskaia, E.A. (2014). Sovremennye zapadnye upravlencheskye modely: syntez [Modern Western Management Models: A Synthesis]. New Public Management Good Governance. ARS ADMINISTRANDI, 2, 45-62 [in Ukrainian].

9. Kettl, D. F. (2005). The Global Public Management Revolution. Brookings Institution Press [in English].

10. Tereshchenko, D.A. (2020). Kontseptualni pidkhody do formuvannia mekhanizmiv derzhavnoho rehuliuvannia rozvytku liudskoho kapitalu [Conceptual approaches to the formation of mechanisms of state regulation of human capital development]. Ukraina $u$ svitovykh hlobalizatsiinykh protsesakh: kultura, ekonomika, suspilstvo - Ukraine in the Global Globalization Processes: Culture, Economy, Society : Proceedings of International Research Practice Conference. (pp. 132-135). Kyiv: Vyd. tsentr KNUKiM [in Ukrainian].

11. Pocheptsov, H. (2009). Novi vymohy do komunikatsii vlady z naselenniam. Zaprovadzhennia komunikatsii u suspilstvi [New requirements for communication between the authorities and the population. Introducing communications in society]. Zaprovadzhennia svitovykh standartiv komunikatsii mizh vladoiu ta hromadskistiu - plan dii dlia Ukrainy Implementing world standards for communication between government and the public - an action plan for Ukraine : Proceedings of the round table. (pp. 20-23). Retrieved from http://www.fes.kiev.ua/new/wb/media/publikationen/Com_politics_FINAL.pdf [in Ukrainian].

12. Dombrovska, S.M., Moroz, V.M., Hren, L.M., Leonenko, N.A. \& Moroz, S.A. (2018). Derzhavne upravlinnia zabezpechenniam hendernoi rivnosti v Ukraini [Public Administration for Gender Equality in Ukraine]. Kharkiv: NUTsZU [in Ukrainian].

13. Kovbasiuk, Yu. V. (Eds.) (2014). Mistseve samovriaduvannia v Ukraini: suchasnyi stan ta osnovni napriamy modernizatsii [Local self-government in Ukraine: current state and main directions of modernization]. Kyiv: NADU [in Ukrainian].

14. Park, H., \& Blenkinsopp, J. (2011). The roles of transparency and trust in the relationship between corruption and citizen satisfaction. International Review of Administrative Sciences, 77(2), 254-274 [in English].

15. Romanenko, Ye.O., \& Chaplai, I.V. (2016). Systema marketynhovykh komunikatsii v mekhanizmakh derzhavnoho upravlinnia [System of marketing communications in mechanisms of public administration]. Aktualni problemy ekonomiky - Current problems of the economy, 4, 69-78 [in Ukrainian]. 